\title{
Discrimination in education of children in central and eastern Europe in the jurisprudence of the European Court on Human Rights
}

\section{Velina Todorova}

\begin{abstract}
SUMMARY
This contribution discusses the child's right to education in the context of discriminatory practices of its realisation in some Central and Eastern European states. The discussion is driven by three judgments of the European Court on Human Rights pronounced relatively recently - D.H. and Others $v$ The Czech Republic (2007), Orcus and Others $v$ Croatia (2010) and Horvath and Kiss $v$ Hungary (2013). The judgments are reviewed with the view to demonstrate the way the Strasbourg Court develops its concept of indirect discrimination, incl. of prima facie evidence of discrimination. Also, the contribution is trying to highlight to evolving reasoning of the Court in applying the concept of indirect discrimination in connection with the ones of margin of appreciation and proportionality. An important finding is that the Court finds out that the segregated manner of educating Roma children is not a proportionate tool to achieve the declared (although) a legitimate aim - to respond to the needs of these children. The contribution also focuses on the way the right of the child to education is protected under the Convention on the Rights of the Child and European Convention on Human Rights and Fundamental Freedoms. It proves that although the two international treaties use different approaches, their aims are similar - to ensure equal access to education but also access to quality education that enhances the life chances of children at adulthood.
\end{abstract}

\section{Introduction}

This contribution aims to discuss how the right of the child to education is interpreted in some recent judgements of the European Court on Human Rights, although the European Convention on Human Rights and Fundamental Freedoms (ECHR) does not explicitly protect children's rights. The first reason behind this choice is the nature of this right as a cross cutting right - as a linkage and as a key to the unlocking of other human rights - economic, social and cultural as well as civil and political ones. ${ }^{1}$ Another good reason is the specific case of educational discrimination of Roma children in some post-communist countries in Central and Eastern Europe (CEE) that currently are members to the European Union.

In the past the education systems in the CEE region were delivering universal and free education until the age of 18 . At the same time the

1 See more on this in: Koch, Ida Elisabeth. The Right to Education for Roma Children under the European Convention on Human Rights. Accessed at: https://rwi.lu.se/app/uploads/2012/04/Right-to-Education-for-RomaKoch.pdf on 2019-04-29.

How to cite: Todorova 'Discrimination in education of children in central and eastern Europe in the jurisprudence of the European Court on Human Rights' 2019 De Jure Law Journal 580-596 http://dx.doi.org/10.17159/2225-7160/2019/v52a33 
children with specific needs were directed to special schools, for example - helping schools for children with mental impairments. ${ }^{2}$ The research suggests though, that many Roma children, were educated in those separate (segregated) schools or classes not because of their needs but because of their ethnic origin, ${ }^{3}$ which, after the changes in CEE at the end of the 20th century, was termed as amounting to ethnic or racial discrimination. Litigation before international courts became a powerful tool to combat discrimination in education of children.

The contribution will briefly present the international courts in Europe. Then the way the right of the child to education is protected under the Convention on the Rights of the Child (CRC) and ECHR. Then the evolving jurisprudence of the ECtHR on the educational discrimination of Roma children will be exemplified by three judgments against Czech Republic, Croatia and Hungary. The approach of the ECtHR regarding protection of children's rights will be briefly compared to the one of the Committee on the Rights of the Child.

\section{The International Courts in Europe}

There are two international Courts in Europe that have jurisdiction recognised by the states in the continent. The European Court of Human Rights ${ }^{4}$ oversees the implementation of the European Convention on Human Rights in the 47 Council of Europe member states. ${ }^{5}$ The Convention is the first instrument to give effect to certain of the rights, principally civil and political rights, stated in the Universal Declaration of Human Rights and make them binding. Its ratification is a prerequisite for a state to join the Council or Europe. The economic, social and cultural rights of Europeans are enshrined in the European Social Charter. The European Committee on social rights oversees its implementation.

Central and Eastern European states joined the Council of Europe and the Convention after the democratic changes that took place in the region in 1989-1990. The first countries to join were Bulgaria and Hungary in

2 The author have witnessed the reforms in the educational system and have participated in the reforms of the child care and protection system in Bulgaria (1997-2019).

3 See Kanev, K. The first steps: Evaluation of the Desegregation projects of CSOs in 6 Bulgarian towns. Sofia, 2002, at: https://bghelsinki.org/bg/books/ malcinstva/2002/prvite-stpki-otsenka-na-nepravitelstvenite-desegregatsion ni-proekti-v-shest-grada-na-blgariia/ in Bulgarian only and Strategic Litigation Impacts Roma School Desegregation. Open Society Justice Initiative. Open Society Foundations, 2016.

4 It is a regional human rights judicial body based in Strasbourg, France, created under the auspices of the Council of Europe. It is an international organisation aiming to uphold human rights, democracy and the rule of law in Europe. Founded in 1949, it has currently 47 member states. See more at: https://www.echr.coe.int/Documents/Anni_Book_Chapter01_ENG.pdf

5 The European Convention on Human Rights and Fundamental Freedoms is the first Council of Europe's convention and the cornerstone of all its activities. It was adopted in 1950 and entered into force in 1953. 
1992, followed by Poland, Slovakia and Slovenia in 1993 and 1994 and Serbia - in 2003.

The European Court, or "Strasbourg Court", has jurisdiction to decide complaints ("applications") submitted by individuals and States concerning violations of the Convention or of its Additional Protocols. Individuals, including children, can bring complaints of human rights violations to the Strasbourg Court once all possibilities of appeal have been exhausted in the member state concerned. The person, group or non-governmental organization submitting the complaint does not have to be a citizen of a State party. However, complaints submitted to the Court must concern violations of the Convention allegedly committed by a State party to the Convention and that directly and significantly affected the applicant. The Court's 47 judges are selected by the Parliamentary Assembly of the Council of Europe from a list of applicants proposed by the Member States. In general the Court's judgments are binding on states and should be executed. The implementation of the judgments is monitored by the Committee of ministers to the Council of Europe. $^{6}$

The Court of Justice of the European Union is created under the Treaties of the European Union - the last one of which is the Treaty of the Functioning of the European Union (Lisbon Treaty) and is based in Luxemburg. It interprets European Union law, settles legal disputes between national governments and European Union institutions, and, in certain circumstances, the court decides cases on alleged violations of human rights as stipulated in the European Union Charter of Fundamental Rights. Both courts make reference to each other case law with regard to cases on violations of human rights.

\section{The right to education in CRC and ECHR}

The right to education is formulated differently in the CRC and in the ECHR. Notwithstanding that, the jurisprudence of the Committee on the Rights of the Child and of the ECtHR has reached a lot of common interpretations of the respective norms. CRC articulates the right to education as a human right of the child that creates positive obligations on States parties to realise it in a progressive way, to the maximum extent of resources available (article 4 CRC). ${ }^{7}$ The Committee on the Rights of the Child interprets the right to education alongside the aims of

6 See Annual reports on the execution of judgments of the ECtHR at: https:// www.coe.int/en/web/execution/annual-reports.

7 Article 28, $\$ 1$ CRC: 1 . States Parties recognize the right of the child to education, and with a view to achieving this right progressively and on the basis of equal opportunity, they shall, in particular:

(a) Make primary education compulsory and available free to all;

(b) Encourage the development of different forms of secondary education, including general and vocational education, make them available and accessible to every child, and take appropriate measures such as the introduction of free education and offering financial assistance in case of need; 
education (article $29 \mathrm{CRC}$ ), ${ }^{8}$ underlying that it is in the best interests of the child to have access to quality education, including early childhood education, non-formal or informal education and related activities, free of charge 9 and encourages the States parties to develop inclusive education as a set of values, principles and practices that seeks meaningful, effective, and quality education for all students, that does justice to the diversity of learning conditions and requirements not only of children with disabilities, but for all students. ${ }^{10}$ The effective realisation of this right is thoroughly monitored by the Committee. The still existing discriminatory practices is of particular concern, for example, segregated education of Roma children in CEE states. ${ }^{11}$

The right to education is the only social right protected by the ECHR usually read in conjunction with the prohibition of discrimination (article $14 \mathrm{ECHR}$ ). In contrast to the $\mathrm{CRC}$, this right is formulated in a negative way. ${ }^{12}$ This is interpreted as not to create positive obligations to the States parties to develop public education systems but rather to secure access to educational institutions existing at a given time. ${ }^{13}$ However, in the context of the right to education of members of groups suffering past discrimination in education with continuing effects (e.g. Roma children), the Court enshrines the notion of the positive obligations in order to address these problems, such as active and structured involvement on the part of the relevant social services (see Oršus and Others, § 177) or specific actions to avoid the perpetuation of past discrimination or discriminative practices, or to undo a history of racial segregation in special schools (see Horvath and Kiss, § 116, 127). ${ }^{14}$ The ECtHR pays

(c) Make higher education accessible to all on the basis of capacity by every appropriate means:

(d) Make educational and vocational information and guidance available and accessible to all children;

(e) Take measures to encourage regular attendance at schools and the reduction of drop-out rates.

8 See General Comment no. 1 (2001) Article 29(1): The Aims of Education. $\mathrm{CRC} / \mathrm{GC} / 2001 / 1$.

9 See General comment No. 14 (2013) on the right of the child to have his or her best interests taken as a primary consideration (art. 3, para. 1), $\$ 79$.

10 See General comment No. 9 (2006) The rights of children with disabilities (\$62, 65-69). CRC/C/GC/9.

11 See Concluding Observations to government reports of Hungary $(\mathrm{CRC} / \mathrm{C} /$ $\mathrm{HUN} / \mathrm{CO} / 3-5$ of $2014, \S 52-54$ ) and of Bulgaria (CRC/C/BGR/CO/3-5 of 2016, $\S 48-49)$.

12 Article 2 of Protocol No. 1: "No person shall be denied the right to education. In the exercise of any functions which it assumes in relation to education and to teaching, the State shall respect the right of parents to ensure such education and teaching in conformity with their own religious and philosophical convictions."

13 Council of Europe. Guide on Article 2 of Protocol No. 1 to the European Convention on Human Rights. Right to education. Updated on 31 August 2018.

14 See Harris, D., O’Boyle, M. et al. Law of the European Convention on Human Rights. Oxford University Press, 2014, pp. 1083-1086. Also: Kilkelly, U. Religion and Education: A Children's Rights Perspective. A paper delivered at the TCD/IHRC Conference on Religion and Education, Trinity College Dublin, 20 November 2010. 
specific attention to the quality of education, which should increase the life chances of children helping them to integrate into the ordinary schools and to develop the skills that would facilitate life among the majority population (see Horvath and Kiss, § 127).

\section{Discrimination in education of Roma children}

The educational segregation of Roma children in post-communist countries in CEE is a lasting tradition. Research shows that various inter- related mechanisms may lead to the segregation of Roma students such as the so called process of 'white flight', testing of the levels of 'maturity' or of the learning abilities or of language proficiency of young children, residential segregation of Roma families, demographic reasons etc. ${ }^{15}$ In Bulgaria, for example, Roma children were overrepresented in the so called 'helping schools' - a type of boarding schools for care and education of children with mild mental impairments. ${ }^{16}$ Although the segregation in education is addressed by numerous political documents in the region (presenting mainly the good intentions of the political class), as well as by academic studies and projects implemented by civil society organisations, the outcomes are not satisfactory. ${ }^{17}$

Part of the actions addressing discrimination in education is the successful strategic litigation in some CEE that ended up with cases brought before the ECtHR. Three cases will be presented here that illustrate the evolving jurisprudence of the Strasbourg court concerning attention to the applications claiming discrimination in education on the basis of ethnic origin.

15 See more in: Education: the situation of Roma in 11 EU Member States. Roma survey - Data in focus. (2014) FRA - European Union Agency for Fundamental Rights, pp.43-48. At: https://fra.europa.eu/sites/default/files/ fra_uploads/fra-2014-roma-survey-dif-education-1_en.pdf

16 Kunev, K. The first steps: Evaluation of the Desegregation projects of CSOs in 6 Bulgarian towns. Sofia, 2002, at: https://bghelsinki.org/bg/books/malcin stva/2002/prvite-stpki-otsenka-na-nepravitelstvenite-desegregatsionniproekti-v-shest-grada-na-blgariia/ in Bulgarian only.

17 See the monitoring reports of civil society on the implementation of the National Roma Integration Strategies in the EU. The First monitoring cycle (2017) reviewed key structural preconditions of successful implementation of the Strategies: fighting discrimination and antigypsyism, governance and overall policy framework (including Roma participation, coordination structures, use of European Structural and Investment Funds) and for the countries with largest Roma communities (Bulgaria, Czech Republic, Hungary, Romania, Slovakia) also the impact of mainstream education policies on Roma. In the Second monitoring cycle (2018), the reports focus on the key policy areas of education, employment, healthcare and housing. At https://cps.ceu.edu/roma-civilmonitor-reports 
Two of the cases were reviewed by the Grand Chamber of the ECtHR ${ }^{18}$ - D.H. and Others $v$ The Czech Republic (2007), and Orcus and Others $v$ Croatia (2010). The most recent similar case - Horvath and Kiss $v$ Hungary (2013), was decided by the Second section ${ }^{19}$ of the Court.

In D.H. and Others $v$ The Czech Republic, ${ }^{20}$ the applicants - eighteen Roma children, Czech nationals, alleged, inter alia that they had been discriminated against in the enjoyment of their right to education on account of their race or ethnic origin. The applicants were placed in special schools in Ostrava, either directly or after a spell in an ordinary primary school. Those schools were intended for children with mental deficiencies $^{21}$ who were unable to attend "ordinary" or specialised primary schools. ${ }^{22}$ This practice has made it more difficult for Roma children to gain access to other levels of education, thus reducing their chances of integrating in society. Although legislation no longer prevented children from advancing from special to ordinary secondary

18 The Grand Chamber of the Court is a formation of seventeen judges (art. 26/1 of the Convection). The Grand Chamber could consider cases on two occasions. Any Chamber (a composition of seven judges) at any time before it has rendered its judgment, may relinquish jurisdiction in favour of the Grand Chamber, unless one of the parties to the case objects, where a case pending before a Chamber raises a serious question affecting the interpretation of the Convention or the protocols thereto, or where the resolution of a question before the Chamber might have a result inconsistent with a judgment previously delivered by the Court (art.30 ECHR). Article 43 stipulates that referral to the Grand Chamber may be requested by any party to the case, in exceptional cases, within a period of three months from the date of the judgment of the Chamber. A panel of five judges of the Grand Chamber shall accept the request if the case raises a serious question affecting the interpretation or application of the Convention or the Protocols thereto, or a serious issue of general importance. The judgment of the Grand Chamber shall be final (art. 44 ECHR).

19 A Section is an administrative entity and a Chamber is a judicial formation of the Court within a given Section. The Court has five Sections in which Chambers are formed. See Rules of Court at: https://www.echr.coe.int/ documents/rules_court_eng.pdf

20 Application no. 57325/00.

21 The original language of the Judgment is preserved. In all three discussed here judgments the Court applied terminology not consistent with the Convention on the Rights of Persons with disabilities although it was adopted in 2006.

22 D.H. v Czech Republic, \&16: under the terms of the Schools Act (Law no. 29/ 1984), the legislation applicable in the present case, special schools were a category of specialised school (speciálni školy) and were intended for children with mental deficiencies who were unable to attend "ordinary" or specialised primary schools. Under the Act, the decision to place a child in a special school was taken by the head teacher on the basis of the results of tests to measure the child's intellectual capacity carried out in an educational psychology centre and was subject to the consent of the child's legal guardian. The testing, however, was neither compulsory nor automatic. The recommendation for the child to sit the tests was generally made by teachers - either when the child first enrolled at the school or if difficulties were noted in its ordinary primary-school education - or by paediatricians (\$39). 
schools, the level of education offered by special schools generally did not make it possible to cope with the requirements of secondary schools, with the result that most dropped out of the system $(\S 74,144-145)$.

The case was first examined by the Second Section of the Court, which found in 2006 no violation of Article 2 of Protocol No. 1 taken alone or in conjunction with Article 14 of the Convention. The judgment was based on two premises. The state enjoys a margin of appreciation to justify the difference in treatment by differences in otherwise similar situations but also in establishing its policy in the field of education. In this case the Court accepted that the rules governing children's placement in special schools do not refer to the pupils' ethnic origin, but pursue the legitimate aim of adapting the education system to the needs and aptitudes or disabilities of the children. Further on, the Court stated that the States cannot be prohibited from setting up different types of school for children with difficulties or implementing special educational programmes to respond to special needs in the difficult exercise to balance the various competing interests. It further pointed out, that it is not its task to assess the overall social context in the respective state (therefore refused to rely on the statistics presented) but rather it is tasked to examine the individual applications before it and to establish on the basis of the relevant facts whether the reason for the applicants' placement in the special schools was their ethnic or racial origin.

On the request of applicants, the case was transferred to the Grand Chamber, which decided in 2010 exactly the opposite. The Court particularly examines the practice of psychological testing of children in place to justify their entry to the special educational system. It is observed that the tests, although regarded for all children, are not culturally and linguistically sensitive, and do not take into account the former (lack) of experience as well as the lack of preschool education of Roma children $(\S 40-47)$. Therefore, the testing results in overrepresentation of children in special needs education designated at that time for children with mental health problems, fact that is supported by various reports. ${ }^{23}$ The role and attitudes of the Roma and non-Roma parents were examined too as a factor for educational segregation. The role of teachers to direct children to special educational classes or to encourage parents to agree on that are also considered by the Court $(\$ 49)$.

23 The Advisory Committee on the Framework Convention for the Protection of National Minorities noted in its first report on the Czech Republic (2002), that while these schools were designed for mentally handicapped children it appeared that many Roma children who were not mentally handicapped were placed in them owing to real or perceived language and cultural differences between Roma and the majority. In its second report (2005) this Committee noted with concern that "Roma account for up to $70 \%$ of pupils in [special] schools, and this - having regard to the percentage of Roma in the population - raises doubts concerning the tests' validity and the relevant methodology followed in practice". In its report on the Czech Republic (2000), the European Commission against Racism and Intolerance (ECRI) noted that channelling of Roma children to special schools was 
The facts and observations makes the Court to accept that this is a case of indirect discrimination: the allegation is not that Roma children are in a different situation from non-Roma children that called for different treatment or that the respondent State had failed to take affirmative action to correct factual inequalities or differences between them. ${ }^{24}$ Accordingly, the issue is whether the manner in which the legislation was applied in practice has resulted in a disproportionate number of Roma children being placed in special schools without justification, and whether such children were thereby placed at a significant disadvantage. The Court points that the facts of the case do not ascertain intentional difference in treatment between Roma and non-Roma children in the area of education but rather the difference in treatment takes the form of disproportionately prejudicial effects of a general policy or measure which, though couched in neutral terms, discriminates against a group $(\S 129,185-186)$. References to additional sources, for instance Council Directives 97/80/EC and 2000/43/EC and the definition provided by ECRI, support the view that such a situation may amount to "indirect

reported to be often quasi-automatic. In his final report on the human rights situation of the Roma, Sinti and Travellers in Europe (2006), the Commissioner for Human Rights observed: "Roma children are frequently placed in classes for children with special needs without an adequate psychological or pedagogical assessment, the real criteria clearly being their ethnic origin." In addition the Commissioner points out Being subjected to special schools or classes often means that these children follow a curriculum inferior to those of mainstream classes, which diminishes their opportunities for further education and for finding employment in the future. The automatic placement of Roma children in classes for children with special needs is likely to increase the stigma by labelling the Roma children as less intelligent and less capable. At the same time, segregated education denies both the Roma and non-Roma children the chance to know each other and to learn to live as equal citizens. It excludes Roma children from mainstream society at the very beginning of their lives, increasing the risk of their being caught in the vicious circle of marginalisation." D.H. v Czech Republic, $\$ 41-43$ and 50.

24 See also Harris, D., O'Boyle, M. et al. Law of the European Convention on Human Rights, pp.976 et seq. The different treatment does not come from the wording of the law. The Government presented several facts of legal and policy changes after the 1990, but these were not convincing to the Court: provision of additional lessons for pupils who had completed their compulsory education in a special school; preparatory classes for children from disadvantaged social backgrounds have been opened in nursery, primary and special schools; an alternative educational curriculum for children of Roma origin who had been placed in special schools; Roma teaching assistants were also assigned to primary and special schools to assist the teachers and facilitate communication with the families. By virtue of amendment no. 19/2000 to the Schools Act, pupils who had completed their compulsory education in a special school were also eligible for admission to secondary schools, provided they satisfied the entrance requirements for their chosen course (D.H. v Czech Republic, \$16-17). The new Act on school education (No 651 of 2004) no longer provides for special schools in the form that had existed prior to its entry into force. Primary education is now provided by primary schools and specialised primary schools, the latter being intended for pupils with severe mental disability or multiple disabilities and for autistic children (D.H. $v$ Czech Republic, \$31-33). 
discrimination", which does not necessarily require a discriminatory intent $(\S 184)$.

The Court points out that it is difficult to prove indirect discrimination and a prima facie evidence is needed in order the burden of proof to be shifted to the Government $(\$ 183)$. The evidence is needed to make an assessment whether the impact of a measure or practice on an individual or group, constitutes a discrimination. The Court accepts in this case that the statistics suggesting that in 1999 Roma pupils made up between $80 \%$ and $90 \%$ of the total number of pupils in some special schools and that in 2004 "large numbers" of Roma children were still being placed in special schools is such prima facie evidence $(\S 192,196)$.

The Government has failed to convince the Court that the disproportionately high number of Roma children in special schools could be explained by the results of the intellectual capacity tests or be justified by parental consent ${ }^{25}$ nor that the results of the tests are capable of constituting objective and reasonable justification for the purposes of Article 14 of the Convention (\$197-199). Therefore the Chamber conclude that the facts "of the case indicate that the schooling arrangements for Roma children were not attended by safeguards that would ensure that, in the exercise of its margin of appreciation in the education sphere, the State took into account their special needs as members of a disadvantaged class.

The next point is also very important. The Court reiterates its notion that the education should be of such a quality that would allow children to benefit and increase their life chances. The Court notes in this judgment that the education that children received in such a segregated manner compounded their difficulties and compromised their subsequent personal development instead of tackling their real problems or helping them to integrate into the ordinary schools and develop the skills that would facilitate life among the majority population" ( $\$ 207$ ). In these circumstances the Court is not satisfied that the difference in treatment between Roma children and non-Roma children is objectively and reasonably justified and that there existed a reasonable relationship of proportionality between the means used and the aim pursued. Therefore, the Court finds that there has been a violation of Article 14 of the Convention taken in conjunction with Article 2 of Protocol No. 1 as regards each of the applicants (\$ 208-209).

In Orsus and others $v$ Croatia, ${ }^{26}$ the applicants - fourteen Croatian children, attended separate classes, comprising only Roma pupils, at the

25 With regard to parental consent the Chamber stated that: In view of the fundamental importance of the prohibition of racial discrimination the Grand Chamber considers that, even assuming the conditions were satisfied, no waiver of the right not to be subjected to racial discrimination can be accepted, as it would be counter to an important public interest ( $\S$ 204).

26 Application no. 15766/03. 
ordinary primary schools in two villages. ${ }^{27}$ Some of the applicants attended Roma only classes, others both - Roma only and mixed classes during their schooling. The legitimate ground submitted by the Government, to justify the entry of these children in segregated classes was the insufficient language proficiency. ${ }^{28}$ The applicants, however, alleged inter alia, that they had been denied the right to education and discriminated against in the enjoyment of that right on account of their race or ethnic origin.

The Grand Chamber points out in this case "that the central question to be addressed is whether adequate steps were taken by the school authorities to ensure the applicants' speedy progress in acquiring an adequate command of Croatian language and, once this was achieved, their immediate integration into mixed classes. In this connection, the curriculum followed by the applicants and the procedures concerning their transfer to mixed classes appear of high importance" $(\S 145)$. The Chamber also raises the important issue of the necessary "positive measures" to address the failure of children to complete primary education or to attain an adequate level of language proficiency, as well as the high drop-out rate of Roma pupils ( $\$ 177$ ).

Unlike in D.H. case in this case, the Court does not find the statistical data as prima facie evidence for discrimination. However, the Court notes that "the measure of placing children in separate classes on the basis of their insufficient command of the Croatian language was applied only in respect of Roma children, which clearly represents a difference in treatment" ( $\S 153)$. Therefore, it is concluded again, that the schooling arrangements for Roma children were not sufficiently attended by safeguards that would ensure that, in the exercise of its margin of appreciation in the education sphere, the State had sufficient regard to their special needs as members of a disadvantaged group ( $\S 182)$. This allows the Chamber to determine a lack of a reasonable relationship of proportionality between the means used and the legitimate aim said to be pursued. Finally, the Court finds that the difference in treatment of Roma children amounts to discrimination in violation of Article 14 of the Convention taken together with Article 2 of Protocol No. 1 ( $\S 184-185)$.

In Horvath and Kiss $v$ Hungary $(2013)^{29}$ the applicants are two young Roma men, who are diagnosed as having mental disabilities. As a result,

27 The Application was initially reviewed by the First Section of the Court, which found in 2008 no discrimination. It held that the applicants had been assigned to Roma-only classes because they lacked sufficient command of the Croatian language and that this measure had been justified $(\S 4,112)$. The case was referred to the Grand Chamber on the applicants' request.

28 Like in D.H. case, this case has been reviewed by the First Section of the Court in 2008 found no violation of Article 2 of Protocol No. 1 taken alone or in conjunction with Article 14 of the Convention. It held that the applicants had been assigned to Roma-only classes because they lacked sufficient command of the Croatian language and that this measure had been justified.

29 Application no. 11146/11. 
the applicants were educated at a remedial school "special educational programme" or "special" school) created for children with mental disabilities. The Court finds again (as in D.H. case) that Roma appear to have been overrepresented in the past in remedial schools due to the systematic misdiagnosis of mental disability; that this general policy or measure exerted a disproportionately prejudicial effect on the Roma, a particularly vulnerable group, even the policy or the testing in question may have had similar effect on other socially disadvantaged groups as well. However, the different, and potentially disadvantageous, treatment applied much more often in the case of Roma than for others $(\$ 110)$. The Court again points out the positive obligation of the state to avoid the perpetuation of past discrimination or discriminative practices and to ensure quality education that supports the integration of students into the society $(\$ 116,127)$.

The Court accepts that the schooling arrangements for Roma applicants with allegedly mild mental or learning disability have not been attended by adequate safeguards (e.g. needed to avoid the misdiagnosis and misplacement of the Roma applicants) that would ensure that, in the exercise of its margin of appreciation in the education sphere, the State took into account their special needs as members of a disadvantaged class. Therefore they have necessarily suffered from the discriminatory treatment, which constitutes a violation in the instant case of Article 14 of the Convention taken in conjunction with Article 2 of Protocol No. 1 in respect of each of the applicants $(\$ 127-129)$.

\section{The evolving approach of ECtHR and the jurisprudence of the UN Treaty bodies}

The judgments in review were pronounced between 2006 and 2013. All the cases are strategic litigation cases ${ }^{30}$ that have reached the national highest court instances and in Croatia and Czechia - the Constitutional courts. The litigation have been supported by civil society organisations - mostly by Roma Rights Centre placed in Budapest. All three cases concern a violation of children's right to education, protected by a treaty not explicitly devoted to children. The violations also infringe the UN CRC that as an obvious globally agreed human rights standard for children. The Strasbourg Court, however, has failed to apply the arguments already developed in the jurisprudence of the Committee on the Rights of the Child in particular with regard to the discrimination of Roma children, quality of education that is interconnected with the indirect discrimination as well as inclusive education. ${ }^{31}$ The CRC only appears in the 'relevant law' section of the judgments rather than as a source of

30 See more on this in Strategic Litigation Impacts Roma School Desegregation in supra n. 3.

31 See $\S 49$ of D.H. and Others $v$ Czech Republic. 
reference in the reasoning, which diminishes its value. ${ }^{32}$ For example, in 2001 the Committee stated that educational discrimination affects primarily children from remote, rural areas, children from low income families; girls; children with disabilities; children with ethnic minority and migrant backgrounds. ${ }^{33}$ Discrimination in education both direct and indirect, takes different forms - such as misdiagnosis of mild disability, uneven budgetary support to schools that could attract parents to schools receiving higher subsidies, leaving other schools but also parents and children to operate on unequal basis, differentiation in standards for school enrolment, curriculum, textbooks etc. ${ }^{34}$

The above reviewed judgments demonstrate the way the Strasbourg Court develops its concept of indirect discrimination, incl. of prima facie evidence and shifting the burden of prove. In all three cases the issue is indirect discrimination on the ground of ethnic origin in the access to but also in relation to the quality of education. This form of discrimination is defined by the Court as: as difference in treatment whether the manner in which the legislation was applied in practice resulted in a disproportionate number of Roma children being educated in a segregated manner out of the mainstream education.

In its reasoning, the Court disagreed with the respective Governments that the placement of Roma children in special primary schools for children with specific educational needs in Czechia (D.H., $\S$ 15-16), or in separate classes in the mainstream primary school in Croatia (Orsus, $\S$ $10)$, or in special (remedial) schools for children with mental disabilities in Hungary (Horvath, $\S 6-8$ ) is justified by a legitimate aim - to respond to the special educational needs of those children (learning deficits D.H., $\S 15$; insufficient command of the Croatian language - Orsus, $\S 158$; and mental disability, Horvath, $\$ 6$ ). The Court rather accepted that the placement has been done on the basis of their ethnic origin proved by various statistical data, reports and other sources. Therefore, the Court concluded that the means of achieving that aim were not appropriate and necessary. The Court pointed out that the children were thereby placed at a significant disadvantage compared to other children. As a result Roma children received an education, which compounded their difficulties and compromised their subsequent personal development, instead of tackling their real problems or helping them to integrate into the ordinary schools and develop the skills that would facilitate life among the majority population. Therefore, the Court found that without

32 See Florescu, S., Liefaard, T. \& Bruning, M. Children's rights and the European convention on human rights. Accessed at https://openaccess. leidenunivnl/bitstream/handle/1 887/39663/000-06-NJCM \% 202015\% 20 nr \% 20\% 204\%20Florescu \% 20Liefaard \% 20Bruning.pdf?sequence $=1$.

$33 \mathrm{CRC} / \mathrm{GC} / 2001 / 1, \S 10$.

34 About the recent trend in Hungary - the state strengthens the religious schools, See Church schools receive three times more funding than state schools and Church schools taking over in Hungary's poorer regions, at: https://budapestbeacon.com/report-church-schools-receive-three-timesfunding-state-schools/ accessed on 30.04.19. 
objective and reasonable justification, Roma children were treated less favourably than non-Roma children in a comparable situation and that this amounted to indirect discrimination, which was a violation of the Convention rights.

This reasoning leads the Strasbourg court close to the concept of inclusive education developed mostly in the Convention of the Rights of Persons with Disabilities (CRPD) ${ }^{35}$ but also, gradually, in the jurisprudence of the Committee on the Rights of the Child. ${ }^{36}$ Both the CRPD and the related jurisprudence of CRC, were developed during the same period of time - $2000-2013$ and further.

The ECtHR touches briefly upon the issue of inclusive education in Horvath and Kiss. For instance, it was found that in Hungary part of the reason for many children to be considered disabled was that the legal definition of special educational went beyond mental disability and included educational challenge, dyslexia and behavioural problems. ${ }^{37}$ Similar legislation existed for years in many states in CEE. ${ }^{38}$ In its Concluding observations to states parties, the Committee on the Rights of the Child also recommends that measures should be adopted to monitor and effectively eradicate the educational segregation of Roma children, and ensure that context sensitive procedures based on scientific methods are used in assessing disability by all experts. ${ }^{39}$ This view is largely supported by the jurisprudence of the ECtHR, which states that a lack of discriminatory intent in education policies is not sufficient. The States are under a positive obligation to take effective measures against segregation. Measures cannot be regarded as reasonable and proportionate where they result in an education, which compounds the difficulties of Roma children and compromises their subsequent personal development instead of tackling their real problems or helping them to integrate into the ordinary schools.

The Committee on the Rights of the Child shares the same opinion that inclusive education is the most appropriate means to guarantee the principles of non-discrimination and universality of education. Therefore it recommends the state parties to strengthen efforts to promote inclusive education for all children. ${ }^{40}$

35 According to article 24, paragraph 1, CRPD, States parties must ensure the realization of the right of persons with disabilities to education through an inclusive education system at all levels, including pre-schools, primary, secondary and tertiary education, vocational training and lifelong learning, extracurricular and social activities, and for all students, including persons with disabilities, without discrimination and on equal terms with others.

36 See CRC/C/GC/9: $\$ 62,65-69$.

37 Horváth and Kiss v Hungary, §9-15.

38 This was the case in Bulgaria where the Education Act, outlawed in 2016, provided for so called 'helping schools' for children with light mental health problems, where Roma children were also overrepresented.

39 See concerns and recommendations to Czechia: CRC/C/CZE/CO/3-4 (2011), § 61-62 and to Hungary: CRC/C/HUN/CO/3-5, (2014), § 52-53.

40 GC N 9 (2006) on the 'Rights of Children with Disabilities'. 
In each of the cases though, the Court touches upon the issue of direct discrimination too, noting that Article 14 ECHR does not prohibit a member State from treating groups differently in order to correct "factual inequalities" between them; indeed in certain circumstances a failure to attempt to correct inequality through different treatment may in itself give rise to a breach of the Article. Thus the ECtHR comes closer to the notion expressed by the Committee on the Rights of Persons with Disabilities $^{41}$ that:

"Equalization of opportunities, as a general principle of the Convention under article 3, marks a significant development from a formal model of equality to a substantive model of equality. Formal equality seeks to combat direct discrimination by treating persons in a similar situation similarly. It may help to combat negative stereotyping and prejudices, but it cannot offer solutions for the "dilemma of difference", as it does not consider and embrace differences among human beings. Substantive equality, by contrast, also seeks to address structural and indirect discrimination and takes into account power relations. It acknowledges that the "dilemma of difference" entails both ignoring and acknowledging differences among human beings in order to achieve equality.

Inclusive equality is a new model of equality developed throughout the Convention. It embraces a substantive model of equality and extends and elaborates on the content of equality in: (a) a fair redistributive dimension to address socioeconomic disadvantages; (b) a recognition dimension to combat stigma, stereotyping, prejudice and violence and to recognize the dignity of human beings and their intersectionality; (c) a participative dimension to reaffirm the social nature of people as members of social groups and the full recognition of humanity through inclusion in society; and (d) an accommodating dimension to make space for difference as a matter of human dignity. The Convention is based on inclusive equality."

Furthermore, considering the fact that an excessive numbers of Roma children in CEE states ${ }^{42}$ have been educated separately from other children from the majority population the Court evolves (from the D.H. Second section Judgment of 2006 to Horvath and Kiss Judgment of 2013) ${ }^{43}$ its notion that the issue is not only legal but also a public policy issue. Constantly noting the difficulty to prove indirect discrimination due to it taking a form of non-explicitly intentional policy or legislation, the Court invoked non-traditional sources of evidence that in fact supported that view. Those are statistical data, reports of the Council of Europe monitoring bodies (ECRI), reports of the Council of Europe Commissioner on human rights and national and international nongovernmental organisations. Historical and scientific evidences were also presented in the judgments.

41 See General comment No. 6 (2018) on equality and non-discrimination. CRPD/C/GC/6, $\&$ 10-11.

42 See D.H. $\$ 18,43,65$; Horvath and Kiss: $\$ 115,128$.

43 It should be noted that this is not an anonymous position of the Grand Chamber - see dissenting opinions in those judgments. 
This type of reasoning as pertaining more to the 'common law' litigation was not accepted unanimously in the Grand Chamber. ${ }^{44}$ Several judges were reluctant to accept the educational policy in the related states as a human rights issue but rather as a matter of social policy where the state has a wide margin of appreciation. ${ }^{45}$ The majority, however, clearly departed from the strictly legalistic approach probably because was confronted by a serious and common for many CEE states problem - not only legal but also social. The last judgment of Horvath and Kiss $v$ Hungary was the only one taken unanimously. Taking this stance the Court calls for a positive actions from the respective Governments to address the issue in a holistic way.

Last but not least, it is noteworthy that the Strasbourg Court and the Committee on the Rights of the Child always make a very strong connection between the right to access to education and its quality that should allow the student to benefit later from the education received. This justified the Court's finding that the schooling arrangements for Roma children were not attended by safeguards that would ensure that, in the exercise of its margin of appreciation in the education sphere, the State took into account their special needs as members of a disadvantaged class. The statistics also demonstrated that the proportion of Roma children graduated from school has been much lower than the one of children from majority population. The CRC Committee also notes that discrimination on the basis of any of the grounds listed in article 2 of the Convention, whether it is overt or hidden, offends the human dignity of the child and is capable of undermining or even destroying the capacity of the child to benefit from educational opportunities. While denying a child's access to educational opportunities is primarily a matter, which relates to article 28 of the Convention, there are many

44 See dissenting opinion of Judge Borrego Borrego (Oršuš and Others, §9): In contradiction with the role which all judicial bodies assume, the entire judgment is devoted to assessing the overall social context - from the first page ("historical background") to the last paragraph, including a review of the "Council of Europe sources" (fourteen pages), "Community law and practice" (five pages), United Nations materials (seven pages) and "other sources" (three pages, which, curiously, with the exception of the reference to the European Monitoring Centre, are taken exclusively from the AngloAmerican system, that is, the House of Lords and the United States Supreme Court). Thus, to cite but one example, the Court states at the start of paragraph 182: "The Court notes that as a result of their turbulent history and constant uprooting the Roma have become a specific type of disadvantaged and vulnerable minority." The judge is also very critical to the majority that named the educational discrimination - as racial discrimination.

45 According to the eight dissenting judges in Orsus $v$ Croatia, "it is accepted that decisions pertaining to the methods used to address the special needs of certain pupils belong to the sphere of social policy, in which States enjoy quite a wide margin of appreciation. Therefore, placing the applicants in separate classes as a means of addressing their special needs is not as such contrary to the Convention, either from the standpoint of Article 2 of Protocol No. 1 or from that of Article 14 of the Convention." Therefore, these judges conclude, it is not shown in this case that the applicants were put at a particular disadvantage compared with other pupils by their placement in Roma-only classes at times during their primary education 
ways in which failure to comply with the principles contained in article 29 (1) can have a similar effect.

Furthermore, the CRC Committee always links the right to education with its goals as enshrined in Article $29 \mathrm{CRC}$, which provides the qualitative dimension of the education. The education to which every child has a right, is one designed to provide the child with life skills, to strengthen the child's capacity to enjoy the full range of human rights and to promote a culture, which is infused by appropriate human rights values. As the Committee states in its GC No1: "Education in this context goes far beyond formal schooling and knowledge transfer to embrace the broad range of life experiences and learning processes which enable children, individually and collectively, to develop their personalities, talents and abilities and to live a full and satisfying life within society. It also insists upon the need for education to be child-centred, child-friendly and empowering."

\section{Conclusion}

The reviewed jurisprudence demonstrated the position of ECtHR against indirect discrimination in the enjoyment of the right to education of Roma children. It evolved from rejecting violation of the right justified by the margin of appreciation of the state party in the area of education (in the cases D.H. and Orsus reviewed by the sections) to establishing a violation of the right based on indirect discrimination and requesting positive actions to end discrimination. This development could be attributed to various factors as mentioned before. Most importantly it is the activism from the civil society viewing the strategic litigation as valuable tool for social change. The research produced and data collected by the various structures of the Council of Europe have also contributed for the Court to understand the problem. The universal human rights conventions (e.g. CRC and CRPD) and the jurisprudence of their monitoring bodies provide an important back up and potential for the development of the jurisprudence of the ECtHR.

The case law of the ECtHR confirms that the right to education is justiciable right ${ }^{46}$, and if subjected to discrimination - should be secured immediately and fully but not considered as a social or cultural right and thus as a subject to progressive realization. ${ }^{47}$ The contribution also showed that although of different nature, the international monitoring mechanism interpret the international human rights conventions in a similar vein. There is a lot more, however, to be achieved in mutual awareness, knowledge and application of the arguments of different

46 See Koch, Ida Elisabeth. The Right to Education for Roma Children under the European Convention on Human Rights. And also: Strategic Litigation Impacts Roma School Desegregation. Open Society Justice Initiative. Open Society Foundations, 2016.

47 Statement by the Special Rapporteur on the right to education, Commission on Human Rights, 8 April 1999. Cited according to Koch, supra n.2. 
bodies in order to protect and enforce better the human rights of children. 